\title{
Assessment of Pollution Potential of Soil and Groundwater in a Non-Engineered MSW Landfill Site
}

\author{
Kalyan Adhikari and Supriya Pal
}

\begin{abstract}
Assessment of pollution potential of soil and groundwater by MSW landfill leachate in an industrial city of the eastern India has been carried out through physico-chemical characterization of soil and groundwater, identification of priority contaminants, batch adsorption and isotherm studies of priority contaminants. The study region used to receive wastes for 8-10 years in an area of $1000 \mathrm{~m} \times 500 \mathrm{~m}$ before it was abandoned 3 years ago. $\mathrm{Cr}^{6+}$ has been taken as priority contaminant in the leachate because of its presence in the MSW dump site soil as seven times higher $(10.16 \mathrm{mg} / \mathrm{Kg})$ than the CCME standard. Hydrogeologically the dump area underlies potential unconfined aquifer with easterly flow direction of the groundwater. Depth of water table (0.91-5.92 m) suggests a thin zone of aeration which increases the possibility of the contaminant to reach groundwater. Batch equilibrium study revealed that the intermediate soil zone possess good resilience with respect to $\mathrm{Cr}^{6+}$ transport in the subsurface. Freundlich isotherm model provided the best fit $\left(R^{2}=0.9837, \mathrm{RMSE}=0.89\right)$ to $\mathrm{Cr}^{6+}$ batch adsorption results. Multiple binding of $\mathrm{Cr}^{6+}$ was facilitated by the presence of higher concentration iron in the in-situ soil.
\end{abstract}

Index Terms-Adsorption, chromium, groundwater, in-situ soil, isotherm, MSW dumpsite.

\section{INTRODUCTION}

The most common and convincing method to manage the municipal solid waste is the burial in an engineered landfill. In India, most of the urban areas dump their solid waste in open fields either little away from the locality or in the vicinity of the locality. The open waste dumps, apart from odors, rodent and aesthetic nuisance are prone to generate leachate in different stages of interaction under various physico-chemical condition in the subsurface. Once the refuse is very well decomposed, the rate of oxygen diffusion into the landfill may exceed the rate of microbial oxygen depletion [1], [2]. It is quite critical to extrapolate the long term impact of landfill because different parts of a single landfill may undergo different phases of decomposition at the same time. Furthermore, decomposition continues for several years, even after the landfill stops receiving waste.

Groundwater contamination by landfill leachate has been widely reported [3]-[6] around the world. Leachate quality, quantity and their variation with time are not only the controlling factors but also the physicochemical

Manuscript received December 31, 2014; revised May 15, 2015.

Kalyan Adhikari is with the Department of Earth and Environmental Studies, National Institute of Technology Durgapur, West Bengal, India (e-mail:k_adh@yahoo.co.in).

Supriya Pal is with the Civil Engineering Department, National Institute of Technology Durgapur, West Bengal, India (e-mail: supriya.pal@ce.nitdgp.ac.in). characteristics and mineralogical components of soil or rock in the unsaturated and saturated zone are equally important in assessing soil and groundwater pollution.

The objective of the study was to assess the pollution potential of soil and groundwater in a MSW waste dump site and its proximities through physico-chemical characterization of soil and groundwater, identification of priority contaminants, batch adsorption and isotherm studies of priority contaminants.

A MSW open dump located in the Durgapur city, West Bengal, India was operative for 8-10 years before it was abandoned three years ago. The approximate area covered by the waste dump is $1000 \mathrm{~m} \times 500 \mathrm{~m}$. There are villages in the proximity of eastern boundary of the waste dump site. As the MSW dump site is entirely unprotected in terms of leachate generation and migration of leachate in the sub-surface, there are possibilities of formation of contaminant plume in the groundwater beneath the dump. The rural people, living in the proximity of this MSW dump site, may become the victim by consuming this contaminant laden groundwater.

\section{MATERIALS AND METHODS}

\section{A. Sampling of Soil}

The entire landfill area was subdivided into five equal grids (A, B, C, D, E) from which 11 nos. of soil samples were collected by augur boring to predetermined depth. The soil samples were taken to laboratory for physico-chemical analysis.

\section{B. Sampling of Groundwater}

14 number of groundwater samples were collected from dug wells in the close proximity of MSW dumpsite. Out of 14 samples only one sample was collected from the only unlined dug well (L-12) present within landfill. The water samples then analyzed for the parameters like $\mathrm{pH}, \mathrm{TDS}, \mathrm{Cr}, \mathrm{Pb}, \mathrm{Fe}$ and $\mathrm{Zn}$, respectively by using standard methods as described in APHA [7]. Effort was also made to measure depth of water table to prepare the water table contour map of the MSW dump site.

\section{Soil Analysis}

$500 \mathrm{gm}$ of each soil sample was oven dried for three days at temperature of less than $60{ }^{\circ} \mathrm{C}$, so that biomass and volatiles are retained ([8], Puget Sound). For heavy metal analysis, $100 \mathrm{gm}$ of oven dried soil sample was added to $100 \mathrm{ml}$ of 0.1 $\mathrm{N} \mathrm{HCl}, 100 \mathrm{ml}$ of (1:9) phosphoric acid, $100 \mathrm{ml}$ of $0.1 \mathrm{~N}$ nitric acid and $200 \mathrm{ml}$ of distilled water and digested for 2hours; then $50 \mathrm{ml}$ of concentrated $\mathrm{HNO}_{3}$ was added to the suspension and digested for further 30 minutes. The digested suspension 
was transferred to $200 \mathrm{ml}$ of distilled water and then filtered through $0.47 \mu \mathrm{m}$ filter paper. The filtrate was analyzed for $\mathrm{Cd}$, $\mathrm{Cr}, \mathrm{Cu}, \mathrm{Pb}, \mathrm{Ni}, \mathrm{Zn}$ and $\mathrm{As}$ in the ICP following the method stated in APHA [9].

\section{Batch Adsorption Experiment and Adsorption Isotherm}

TABLE I: HEAVY METALS IN IN-SITU SOIL

\begin{tabular}{|c|c|c|c|c|c|c|c|}
\hline Grid & $\begin{array}{l}\mathrm{Cr} \\
(\mathrm{mg} / \mathrm{Kg})\end{array}$ & $\begin{array}{l}\mathrm{Cd} \\
(\mathrm{mg} / \mathrm{Kg})\end{array}$ & $\begin{array}{l}\mathrm{Pb} \\
(\mathrm{mg} / \mathrm{Kg})\end{array}$ & $\begin{array}{l}\text { Fe } \\
(\mathrm{mg} / \mathrm{Kg})\end{array}$ & $\begin{array}{l}\mathrm{Cu} \\
(\mathrm{mg} / \mathrm{Kg})\end{array}$ & $\begin{array}{l}\mathrm{Ni} \\
(\mathrm{mg} / \mathrm{Kg})\end{array}$ & $\begin{array}{l}\mathrm{Zn} \\
(\mathrm{mg} / \mathrm{Kg})\end{array}$ \\
\hline $\mathbf{A}$ & 7.60 & 0.475 & 8.65 & 6025 & 0.09 & 3.83 & 50.70 \\
\hline B & 6.43 & 0.225 & 2.32 & 4732 & 0.09 & 3.80 & 6.85 \\
\hline $\mathbf{C}$ & 11.87 & 0.400 & 4.25 & 9985 & 0.14 & 5.02 & 20.35 \\
\hline D & 12.50 & 0.375 & 3.85 & 7895 & 0.13 & 4.55 & 11.18 \\
\hline $\mathbf{E}$ & 12.38 & 0.425 & 4.07 & 11412 & 0.24 & 7.90 & 2.35 \\
\hline CCME Standard & 1.4 & 1.4 & 70 & --- & 63 & 50 & 200 \\
\hline
\end{tabular}

$\mathrm{Cr}^{6+}$ was taken for batch adsorption because of its dominancy (Table I) in the landfill soil. Laboratory scale batch studies were conducted to investigate the adsorption phenomenon of landfill soil using $\mathrm{Cr}^{6+}$ as an adsorbate. Representative soil samples, used as an adsorbent, were prepared by mixing all the soil samples by coning and quartering method. Chromium solution of initial concentrations $1,2,4,5$ and $10 \mathrm{mg} / \mathrm{L}$ with soil adsorbent dosage ranging between 15 to $120 \mathrm{~g} / \mathrm{L}$ were taken in a series of $100 \mathrm{ml}$ capacity conical flasks. Although the adsorptive affinity of $\mathrm{Cr}^{6+}$ to soil surfaces notably increase in acidic environment [10], but in the present study $\mathrm{pH}$ was maintained at 7 to ensure natural onsite condition where average $\mathrm{pH}$ of the landfill soil sample was found to be 6.72 . Each batch of 6 conical flasks including one blank were placed in an orbital rotary shaker at room temperature $\left(25^{\circ} \mathrm{C}\right)$ and agitated at speed of $160 \mathrm{rpm}$ for 6 hours. The flasks were taken out serially at different predetermined time intervals $(30,90,180$, $360 \mathrm{~min}$ ) one after another from the shaker and the treated solution was filtered through $22 \mu \mathrm{m}$ filter paper. The residuals $\mathrm{Cr}^{6+}$ concentration of filtrate was analyzed spectrophotometrically using UV-VIS spectrophotometer at a wave length of $540 \mathrm{~nm}$ in a $5 \mathrm{~cm}$ cell following the procedure of USEPA, [8]. The standard curve and adsorbance value were used for estimating residual $\mathrm{Cr}^{6+}$ concentration. The percentage of $\mathrm{Cr}^{6+}$ adsorbed by the in-situ soil (landfill soil) calculated by eqn. no. 1 .

$$
\% \text { removal of } \mathrm{Cr}^{6+}=\frac{C_{0}-C_{e}}{C_{0}} \times 100
$$

$C_{0}$ and $C_{e}$ are initial and equilibrium concentrations respectively.

The adsorption isotherm experiments were carried out maintaining a fixed amount of adsorbent dosage with varying initial $\mathrm{Cr}^{6+}$ concentration ranging between $1-10 \mathrm{mg} / \mathrm{L}$ at constant solution $\mathrm{pH}$ level of 7 for each set of experiment as described above. The different adsorbent dosages (15-120 $\mathrm{mg} / \mathrm{L}$ ) were taken for different sets of experiments. After equilibrium, the solutions were filtered and analyzed for residual $\mathrm{Cr}^{6+}$ concentration. The equilibrium $\mathrm{Cr}^{6+}$ adsorption capacity, $\mathrm{S}(\mathrm{mg} / \mathrm{Kg})$ was calculated by Eqn. no. 2 .

$$
S=\frac{\left(C_{0}-C_{e}\right)}{M} \times V
$$

where, $V$ is the volume of solution is in $\mathrm{ml}$ and $M$ is the mass of adsorbent (in-situ soil) in gram.

Langmuir and Freundlich isotherm models, described in Eq. 3 and 4, were applied to derive the isotherm constants.

Linear isotherm,

$$
S=K_{d} C_{e}
$$

Freundlich isotherm,

$$
S=K_{f} C_{e}^{1 / n}
$$

where, $K_{d}(\mathrm{~L} / \mathrm{Kg})$ is the linear isotherm model constant; $K_{f}$ $(\mathrm{L} / \mathrm{Kg})$ and $n$ are Freundlich isotherm constants which were derived using nonlinear regression analysis.

\section{RESULTS AND DISCUSSIONS}

\section{A. Soil Characteristics}

The soil in the study area is silty clay in nature. Average $\mathrm{pH}$ (6.61), depicts that the soil in the dump site is little acidic to neutral. The overall specific gravity of the 11 soil samples ranged between 2.45 and 2.84 . The wide variation of heavy metal contents (Table II) in the dump site may be due to poor sorting or no sorting at all of the rejects, while dumping. Uniform spreading during dumping of the materials was not practised. The solid waste comprises food-wastes, batteries, plastics, rubbers, papers, building materials, metals, scraps, e-waste and other wastes produced in the city. Apart from chromium, other heavy metal concentrations are within the standard as prescribed by CCME (1991) (Table I). Presence of Fe also shows high concentration (avg. $8010 \mathrm{mg} / \mathrm{Kg}$, range: 2747-11413 mg/Kg).

\section{B. Groundwater}

Regional hydrogeology suggests groundwater generally occurs under unconfined to semi confined state. Regional flow is towards south-east [11]. The height of water table in study area and its' proximities varies between 76 and $114 \mathrm{~m}$. It is evident from the water table contour map that permeability of the formation increases towards south with decreasing head. The area of interest of the present study that is the MSW dump area falls under higher permeable region where velocity of groundwater is comparatively slower than the northern part of the study area. 
TABLE II: PHYSICO-CHEMICAL ANALYSIS OF GROUNDWATER OF THE STUDY AREA

\begin{tabular}{|l|l|l|l|l|l|l|l|l|l|l|l|l|}
\hline & L1 & L2 & L3 & L4 & L5 & L6 & L7 & L8 & L9 & L10 & L11 & L12 \\
\hline $\mathrm{pH}$ & 7.54 & 7.43 & 6.93 & 6.90 & 6.95 & 6.60 & 7.66 & 7.40 & 7.66 & 6.96 & 7.63 & 5.5 \\
\hline $\mathrm{TDS}$ & 66 & 170 & 145 & 68.8 & 78.8 & 53.1 & 70 & 210 & 124 & 32.1 & 40.8 & 153 \\
\hline $\mathrm{Cr}$ & 0.01 & 0.01 & 0.01 & 0.01 & 0.01 & 0.01 & 0.01 & 0.01 & 0.01 & 0.01 & 0.01 & 0.01 \\
\hline $\mathrm{Pb}$ & 0.01 & 0.01 & 0.01 & 0.01 & 0.01 & 0.01 & 0.01 & 0.01 & 0.01 & 0.01 & 0.01 & 0.01 \\
\hline $\mathrm{Fe}$ & 0.07 & 0.08 & 0.06 & 0.05 & 0.05 & 0.06 & 0.06 & 0.05 & 0.33 & 0.05 & 0.05 & 0.05 \\
\hline $\mathrm{Zn}$ & 0.04 & 0.01 & 0.02 & 0.01 & 0.01 & 0.01 & 0.01 & 0.01 & 0.01 & 0.01 & 0.01 & 0.01 \\
\hline
\end{tabular}

TABLE III: BATCH ADSORPTION STUDY RESULTS

\begin{tabular}{|c|c|c|c|c|c|c|c|c|c|c|c|c|}
\hline \multirow{3}{*}{$\mathrm{C}_{\mathbf{0}}$} & \multicolumn{12}{|c|}{ Contact Time (minutes) } \\
\hline & \multicolumn{3}{|l|}{30} & \multicolumn{3}{|l|}{90} & \multicolumn{3}{|l|}{180} & \multicolumn{3}{|l|}{360} \\
\hline & $C_{e}$ & \% rem. & $q_{e}$ & $C_{e}$ & \% rem. & $q_{e}$ & $C_{e}$ & $\%$ rem. & $q_{e}$ & $C_{e}$ & $\%$ rem. & $q_{e}$ \\
\hline 1 & 0.11 & 88.8 & 29.6 & 0.094 & 90.6 & 30.2 & 0.130 & 87.0 & 29.0 & 0.114 & 88.6 & 29.5 \\
\hline 2 & 0.32 & 84.2 & 56.1 & 0.274 & 86.3 & 57.5 & 0.272 & 86.4 & 57.5 & 0.233 & 88.3 & 58.9 \\
\hline 4 & 0.55 & 86.3 & 115.0 & 0.525 & 86.9 & 115.8 & 0.521 & 87.0 & 116.0 & 0.516 & 87.1 & 116.1 \\
\hline 5 & 0.68 & 86.3 & 143.8 & 0.617 & 87.7 & 146.1 & 0.781 & 84.4 & 140.6 & 0.703 & 85.9 & 143.2 \\
\hline 10 & 1.61 & 83.9 & 279.8 & 1.513 & 84.9 & 282.9 & 1.630 & 83.7 & 279.0 & 1.643 & 83.6 & 278.6 \\
\hline
\end{tabular}

$C_{\mathrm{o}}$ and $C_{e}$ are the initial and final $\mathrm{Cr}^{6+}$ concentrations in $(\mathrm{mg} / \mathrm{L}), \%$ rem=Percentage Removal, $\% r=\left[\left(C_{\mathrm{o}^{-}} C_{e}\right) / \mathrm{C}_{\mathrm{o}}\right] 100$ and $q_{e}=\left[\left(C_{0^{-}} C_{e}\right) / M\right] V$ in $(\mathrm{mg} / \mathrm{kg})$

Physico-chemical characterisation of groundwater (Table II) reveals that meteoric water during its subsurface journey has not undergone long interaction with the surrounding geological materials which is an indication of recharge zone. All parameters including heavy metals conform to the drinking water standard specified by WHO [12]. L12 (Table II) shows much reduced $\mathrm{pH}$ (5.5) in comparison to the other wells of the study area. L12 is a significant well as it is the only well which is located within the MSW dump area. The $\mathrm{pH}$ of L12 hints about acid phase of decomposition of landfill. Acid phase promotes heavy metal dissolution from the soil, but there is no indication of enrichment of heavy metals in groundwater (Table II). According to the age of land fill (8-10 years) the acid phase should get over by now but unplanned dumping with plastic and building materials might have temporarily mummified the decomposable wastes. Later on tilling activities for vegetable cultivation by poor local people rendered moisture availability to the waste and thereby facilitated the late decomposition. If acid phase continues, the increased rate of heavy metals dissolution from soils and its transport to groundwater in future cannot be ruled out. Presence of chromium in much higher concentration in the landfill soil may pose problem to groundwater in near future. Considering this aspect the soil resilience with respect to chromium has been studied through batch equilibrium studies.

\section{Batch Equilibrium Study}

Laboratory batch tests, involving initial chromium concentrations $(1,2,4,5$ and $10 \mathrm{mg} / \mathrm{L})$ in different adsorbent (in-situ landfill soil) doses $(15,30,60,120 \mathrm{~g} / \mathrm{L})$ for contact time of 360 minutes at $\mathrm{pH}$ of 7 , demonstrate chromium adsorption increases up to $30 \mathrm{~g} / \mathrm{L}$ adsorption dose and thereafter decreases. Table III shows results of batch adsorption study with the optimum soil dose of $30 \mathrm{~g} / \mathrm{L}$. There is no definite trend of change of percentage removal of chromium with contact time for particular initial concentration of chromium. In most cases maximum removal was over $80 \%$ at equilibrium. Maximum removal recorded as 90.6\% with initial concentration $1 \mathrm{mg} / \mathrm{L} . \mathrm{Cr}^{6+}$ adsorption isotherm results were plotted in Linear, Langmuir and Freundlich isotherm model as shown in Fig. 1 - Fig. 3 respectively, and Freundlich isotherm model (coefficient of determination, $r^{2}=0.9837$, RMSE $\left.=0.89\right)$ provided the best fit to the test results (Table III) as compared to the Langmuir isotherm $\left(r^{2}=0.4114, \mathrm{RMSE}=4.52\right)$ and Linear isotherm $\left(r^{2}=0.9785, \mathrm{RMSE}=1.057\right)$ models. The isotherm constants of Freundlich adsorption model were obtained as $K_{f}=9.77 \mathrm{~L} / \mathrm{kg}$ and $1 / n=0.89$. The closer fitting of Freundlich isotherm model with the experiment batch adsorption results also indicates multiple binding and heterogeneity for $\mathrm{Cr}^{6+}$ adsorption in soil media [13].

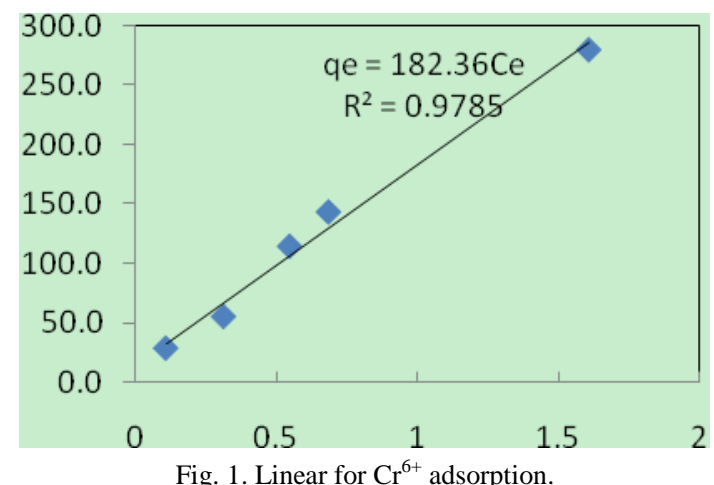

When $1 / n$ value is in the range of $0.1<1 / n<1$, the adsorption process is favourable [14]. In the present investigation the high value of $1 / \mathrm{n}$ clearly indicate that the retardation factor is relatively high and the soil has relatively high $\mathrm{Cr}^{6+}$ attenuation capacity. The maximum amount of $\mathrm{Cr}^{6+}$ adsorbed in soil was found to be $466.6 \mathrm{mg} / \mathrm{Kg}\left(q_{e}=9.77 C e^{0.89}\right)$ at $\mathrm{pH}(7) . \mathrm{Cr}$ normally forms insoluble precipitates with hydroxide [15]. $\mathrm{Fe}^{2+}$ associated with iron oxides/ hydroxide minerals in soils can reduce $\mathrm{Cr}^{6+}$ which results in precipitation (higher partition co-efficient). Experimental data for $\mathrm{Cr}^{6+}$ adsorption onto iron oxy hydroxide and aluminium hydroxide minerals [16], [17] indicate that adsorption increases with decreasing $\mathrm{pH}$ over the $\mathrm{pH}$ range 4-10. Such adsorption behaviour reveals that oxide show a decrease in the number of positively charged surface sites with increasing $\mathrm{pH}$. Presence of high concentration of $\mathrm{Fe}$ in the soil of the present study has played a significant role in overall retardation of $\mathrm{Cr}^{6+}$ in the in-situ soil. Experimental data and peripheral evidences vividly explain that the insignificant concentration of $\mathrm{Cr}^{6+}$ ions in groundwater within the landfill and its proximities where as the concentration of the same in the landfill soils was approximately seven times 
above the standard limit as specified by CCME.

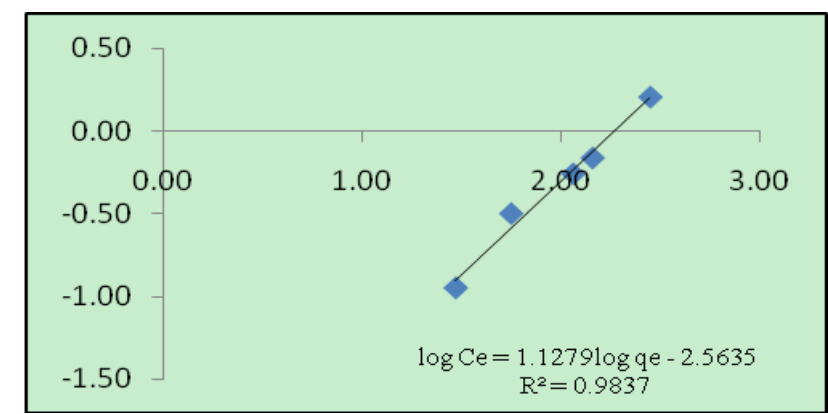

Fig. 2. Freundlich isotherm for $\mathrm{Cr}^{6+}$ adsorption, plot of $\log C_{e}$ against $\log q_{e}$.

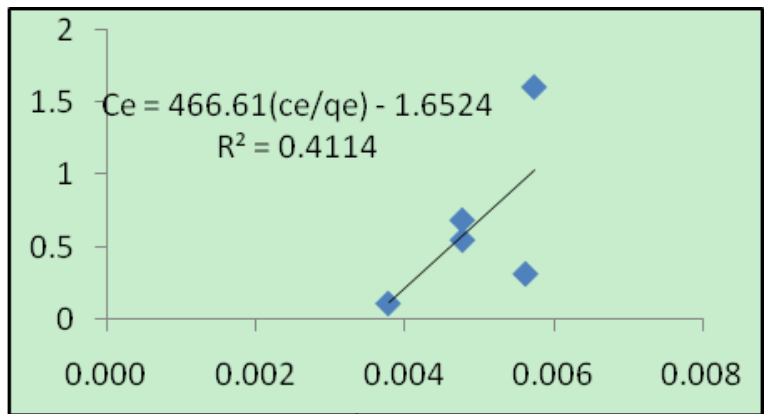

Fig. 3. Langmuir isotherm for $\mathrm{Cr}^{6+}$ adsorption, plot of $C_{e}$ against $C_{e} / q_{e}$.

\section{CONCLUSION}

Activities like tilling of soil for cultivation promotes infiltration of rain water which facilitates in producing leachate from MSW landfill. The $\mathrm{pH}$ (5.5) of the water sample (L12) collected from within the landfill area indicates acid phase of decomposition of the landfill. Although concentrations of $\mathrm{Cr}^{6+}(6.425-12.5 \mathrm{mg} / \mathrm{kg})$ is very high in the in-situ soils but surprisingly groundwater under the landfill and in its proximities contain only $0.01 \mathrm{mg} / \mathrm{l}$ of $\mathrm{Cr}^{6+}$. Laboratory batch tests for $\mathrm{Cr}^{6+}$ with adsorbent as in-situ soil established the best fitted isotherm model is the Freundlich model with $K_{f}=9.77 \mathrm{~L} / \mathrm{kg}$ and $1 / n=0.89$. The experimental results and derived values of the coefficients indicate high $\mathrm{Cr}^{6+}$ attenuation capability of in-situ soils. The resilience of soil with respect to $\mathrm{Cr}^{6+}$ has further increased by precipitation mechanism in the presence of higher $\mathrm{Fe}^{2+}$ content in the in-situ soil.

\section{ACKNOWLEDGMENT}

The authors are thankful to the Director, National Institute of Technology Durgapur-713209, West Bengal, INDIA for providing necessary assistance for carrying out the present research.

\section{REFERENCES}

[1] T. H. Christensen and P. Kjeldsen, "Landfill emissions and environmental impact: An introduction," in Proc. Fifth International Landfill Symposium, vol. 3, CISA, Cagliari, Italy, 1995.

[2] S. Bozkur, L. Moreno, and I. Neretnieks, "Long-term processes in waste deposits," Sci. Total Environ., vol. 250, 2000.

[3] G. A. Gurland and D. C. Mosher, "Leachate effects of improper land disposal," Waste Age, vol. 6, issue 3, p. 42, 1976.

[4] D. S. Mc. Farlane, J. A. Cherry, R. W. Gillham, and E. A. Sudicky, "Migration of contaminants in groundwater at a landfill: A case study," Journal of Hydrology, vol. 63, pp. 1-29, 1983.
[5] M. El-Fadel, A. Findikakis, and J. Leckie, "Environmental impacts of solid waste land filling," Journal of Environmental Management, vol. 50 , issue 1 , pp. 1-25, 1997.

[6] W. J. Dunlap, D. C. Shew, J. M. Robertson, and C. R. Toussaint, "Organic pollutants contributed to groundwater by a landfill, in Gas and leachate from landfills," USEPA, Cincinnati, OH, 1976 , (EPA-600/9-76-004).

[7] APHA, Standard Methods for the Examination of Water and Wastewater, American Public Health Association, Washington DC USA, 1994.

[8] U.S. Environmental Protection Agency (USEPA), Batch Type Procedures for Estimating Soil Adsorption of Chemicals, Office of Solid Waste and Emergency Response, Washington DC, 1992.

[9] Standard Methods for the Examination of Water and Wastewater, American Public Health Association (APHA), 22 ${ }^{\text {nd }}$ edition, Washington DC, USA, 2012.

[10] A. Z. Al-Hamdan and K. R. Reddy, "Surface speciation modeling of heavy metals in Kaolin: Implications for electrokinetic soil remediation processes," Adsorption, vol. 11, no. 5-6, pp. 529-546, 2005.

[11] K. Adhikari, B. Chakraborty, and A. Gangopadhyay, "Assessment of irrigation potential of ground water using water quality index tool," Asian Journal of Water, Environment and Pollution, vol. 10, pp. 11-21, 2013.

[12] Guideline for Drinking Water Quality: Health Criteria and Other Supports Information, vol. 2, 2nd edition., World Health Organization, Geneva, pp. 940-949, 1997.

[13] K. Hanna, L. Lassabatere, and B. Bechet, "Transport of two napthoic acids and salicylic acid in soil: Experimental studies and empirical modeling," Water Research, vol. 46, issue. 14, pp. 4457-4467, 2012.

[14] I. Vazquez, J. R. Iglesias, E. Maranon, L. Castrillon, and M. Alvaeez, "Removal of residual phenols coke wastewater by adsorption," Journal of Haz. Mat., vol. 147, pp. 395-400, 2007.

[15] A. Revans, D. Ross, B. Gregor, M. Meadows, C. Harries, and J. Gronow, "Long-term fate of metals in landfill," presented at Seventh International Waste Management and Landfill Symposium, CISA, Cagliari, Italy, 1999.

[16] J. A. Devis and J. O. Leckie, "Surface ionization and complexation at the oxide/water interface. 3. adsorption of anions," Journal of Colloid Interfacial Science, vol. 74, pp. 32-43, 1980.

[17] R. A. Griffin, A. K. Au, and R. R. Frost, "Effect of $\mathrm{pH}$ on adsorption of chromium from landfill-leachate by clay minerals," Journal Environmental Science Health, vol. 12, pp. 431-449, 1977.

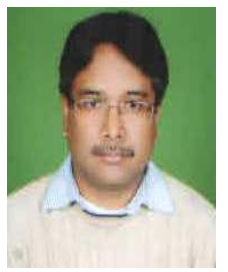

Kalyan Adhikari received the M.Sc. degree in 1991 and the Ph.D degree in 2003 both from the University of Burdwan, West Bengal, India. He is currently an associate professor at National Institute of Technology Durgapur, Department of Earth and Environmental Studies. His research interests are groundwater occurrence, quality, subsurface migration of contaminants and remedies, contaminant removal by natural adsorbents, application of RS and GIS in geoscience. He has published 25 technical papers in reputed national and international journals as well as conference proceedings.

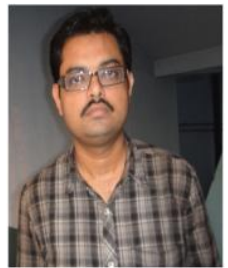

Supriya Pal was born on April 7, 1978 in Mankar, Burdwan, West Bengal, India. He graduated from the Department of Civil Engineering, North Bengal University in 2000. He held the master of civil engineering and the Ph.D from Jadavpur University, Kolkata, India.

$\mathrm{He}$ is currently an assistant professor in the Department of Civil Engineering at National Institute of Technology Durgapur, West Bengal, India. He has 8 years of teaching and research experience in the fields of geotechnical and geo-environmental engineering and 5 years of industrial experience. His research interests are solute transport through porous media, landfill liner design, ground improvement and electrokinetic remediation of contaminated sites. He has directed and supervised numerous research studies and projects in the field of geotechnical and geoenvironmental engineering. He also has 12 research publications in reputed national and international journals and conference proceedings. 